\title{
How Many Isoforms of Keratan Sulfate Proteoglycans are There?
}

\author{
ケラタン硫酸プロテオグリカンには幾つの異型があるのだろうか?
}

Funderburgh, M.L., Funenburgh, J.L., Mann, M., and Conrad, G.W. J. Biol. Chem. (1991) 266, 14266-14233
Jost, C.J., Funderburfh, J.L., Mann, M., and Conrad, G.W. J. Biol. Chem. (1991) 266, 13336-13341

Key Words: core protein, corneal stroma, isoform, keratan sulfate atachment site, keratan sulfate proteoglycan

Keratan Sulfate Proteoglycans(KSPGs) are major components of the corneal stroma after collagen. It is believed that KSPG is involved in the process of corneal transparency. Many investigators have isolated, purified, and characterized KSPGs from monkey, bovine, rabbit, chicken, and human. There is no complete agreement on the number of isoforms of KSPGs present in different mammalian species. Nonetheless, extensive heterogeniety in the structures has been observed. The basis for such an heterogeneity is not clear at present. It may lie in the core proteins, in the glycosaminoglycans(GAGs). The core proteins may have different lengths and different amino acids sequence and may have different $\mathrm{KS}$ attachment sites. The GAG chains may differ in their chain length or the extent of sulfation. The KS chains may have also the bianeternary structure whereby two KS chains may be attached to a common linkage region via two mannose residues.

The authors have attempted to answer some of these questions by isolating core proteins from KSPGs of bovine and chick corneal stromas. In order to do so, these investigators have taken novel approaches; i) Partially purified KSPG preparation was treated with keratanase, with trifluoromethyl sulfonic acid and $N$-glycanase in order to remove KS chains and oligosaccharide chains. The core proteins thus isolated were purified by DEAE-Sephacel chromatography, SDSD-PAGE followed by transfer to nitrocellulose and elution. Three distinct core proteins of molecular sizes of $37 \mathrm{kDa}(37 \mathrm{~A}), 36 \mathrm{kDa}(37 \mathrm{~B})$ and $25 \mathrm{kDa}$ were isolated. ii) Identification of $\mathrm{KS}$ attachment sites on the core proteins was performed by use of specific endo-glycosidase from $E$. freundii which cleaves GlcNAc-GalKS linkage, leaving the linkage region with a bianternary structure and also leaving the non-reducing terminal $\mathrm{N}$-acetyl-glucosamine available for accepting the galactose residue from UDP-Gal catalyzed by galactosyl-transferase. iii) Tryptic peptide mapping of three core proteins showed significant differences. Moreover, distribution of ${ }^{3} \mathrm{H}-\mathrm{Gal}$ labeled peptides as shown by reverse-phase chromatography revealed that $37 \mathrm{~A}$ core protein contained three major ${ }^{3} \mathrm{H}$-peptides indicating three $\mathrm{KS}$ attachment sites. 37B and $25 \mathrm{kDa}$ core proteins contained only ${ }^{3} \mathrm{H}$-peptide suggesting only one KS attachment site. iv) Sialic acid residues on the linkage oligosaccharide portion of the labeled core proteins were selectively labeled with ${ }^{3} \mathrm{H}$ so-
ケラタン硫酸プロテオグリカン(KSPG)は角膜ストローマ 中ではコラーゲンに次いで多い成分であり、KSPGは角膜を透 明にする過程に関わっていると思われている。今までに、サ ル、ウシ、ウサギ、ニワトリ、ヒトからKSPGが抽出精製さ れ、調べられている。哺乳動物の種類が異なるとKSPGの異型 が幾つあるかについての一致した見解はないが、構造には幅の 広い多様性がある。この多様性がコアタンパク質のためか、グ リコサミノグリカン(GAG)にあるのか、判っていない。コアタ ンパク質の長さはまちまちであるし、アミノ酸配列も一様では なく、KS鎖の付く部位も異なっている。GAG鎖も長さや硫酸化 の程度に色々ある。KS鎖には2本側鎖のものがある。つまり、 $\mathrm{N}$ 型糖鎖の共通構造の先に2本のKS鎖が付いている。

この著者はウシとニワトリの角膜ストローマのKSPGのコ アタンパク質を抽出し、これらの疑問に答えようとした。その ために、新しいアプローチを試みている。i)部分精製したKSPG 標品をケラタナーゼ、トリフロオロメタンスルフォン酸や、Nグリカナーゼで処理してKS鎖とオリゴ糖を除いた。こうして得 られたコアタンパク質をDEAE-セファセルクロマトグラ フィー、SDS-PAGEとメンブレンへの転写と溶出で精製した。 分子量 $37 \mathrm{kDa}(37 \mathrm{~A}) 、 36 \mathrm{kDa}(37 \mathrm{~B}) 、 と 25 \mathrm{kDa}$ の明らかに互いに 異なるコアタンパク質3種が得られた。ii) GlcNAc-Gal-KS結合を 切ることのできるE. freundiiのエンドーグリコシダーゼで処理す ると、2本側鎖の結合部分の所のみならず、非還元末端にN-ア セチルグルコサミン残基が出現する。ガラクトース転移醭素を 用いてUDP-Ga1からガラクトースをそこに転移させるという方 法でコアタンパク質にKS鎖の付着している部位を調べた。iii) この3種のコアタンパク質のトリプシンペプチドマップは互いに 明確に異なっていた。のみならず、逆相クロマトグラフィーに おける ${ }^{3} \mathrm{H}-$ ガラクトースで標識されたペプチドを分析すると、37 $\mathrm{A}$ のコアタンパク質には 3 個の ${ }^{3} \mathrm{H}$ 標識のペプチドがあり、これは $\mathrm{KS}$ 鎖の付着部位が3個あることを示している。37Bと25 kDaコア

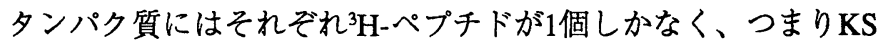
鎖1本が付いていたことになる。iv) 標識されたコアタンパク質 の結合部分のオリゴ糖のシアル酸残基は温和な過沃素酸酸化の 
dium borohydride after mild periodate oxidation. Reversephase chromatographic analysis of tryptic peptides of three core proteins showed the presence of two or four peptides. If the bianternary structure in the linkage region is present both ${ }^{3} \mathrm{H}$ - Gal and ${ }^{3} \mathrm{H}$-borohydride should be present in the isolated linkage region. The analysis showed that $36 \mathrm{kDa}(37 \mathrm{~B})$ and 25 $\mathrm{kDa}$ core proteins contained labeled sialic acid while 37A did not. v) Having shown the presence of three independent isoforms of core proteins, investigators have gone further to demonstrate the presence of three independent messages by using in vitro translational technique. To characterize the initial products of translation, RNA was purified from the bovine corneal stromas and translated in vitro with rabbit reticulocyte lysate. The radioactive protein products produced by incorporation of ${ }^{3} \mathrm{H}$-leucine and ${ }^{35} \mathrm{~S}$-metheonine were immunoprecipated with antiKSPG antibodies, separated by SDS-PAGE. The labeled proteins were elutaed out and further purified by gel chromatography. The precipited core proteins had molecular masses of 53-55 kDa(a doublet) and a single band of $41 \mathrm{kDa}$. These translational products were of higher molecular masses than the core proteins isolated from the tissue.

The authors (in a separate communication) have proposed following models for three isoforms of KSPGs(Fig. 1).
あと ${ }^{3} \mathrm{H}-\mathrm{NaBH}_{4}$ で標識することができる。3種のコアタンパク質 のトリプシン分解ペプチドの逆相クロマトグラフィーではペプ チドが2または4本出現した。結合部分に 2 本側鎖があるなら ${ }^{3} \mathrm{H}-$ Galと ${ }^{3} \mathrm{H}$-ボロヒドリド共に抽出した結合部位になくてはなら ぬ。36 kDa(37B)と25 kDaのコアタンパク質はシアル酸が標識さ れたが、37Aには標識は入らなかった。v)コアタンパク質に3種 の異なる異型の存在することが判ったので、in vitro翻訳法を用 いて3個の独立のタンパク合成指令があるかどうか調べた。翻訳 による一次産物を同定するためにウシ角膜ストローマからRNA を精製し、ウサギ網状赤血球ライゼートを用い、in vitroで翻訳 させた。 ${ }^{3} \mathrm{H}$-ロイシン、 ${ }^{35} \mathrm{~S}$-メチオニンの取り込みで標識させた タンパク質を抗KSPG抗体を用い免疫沈降し、SDS-PAGEで分離 し、さらに抽出してゲルクロマトグラフィーで分けた。こうし て得られた沈降したタンパク質の分子量は $53 \sim 55 \mathrm{kDa}$ (2本鎖)と $41 \mathrm{kDa}$ でった。これらの翻訳産物は組織から抽出したコアタ ンパク質よりも分子が大きかった。

著者は別の報文中でKSPGの3本の異型に対して次のような モデルを提出している(図1)。

彼らのこれらの研究により次のような質問に答える道が拓
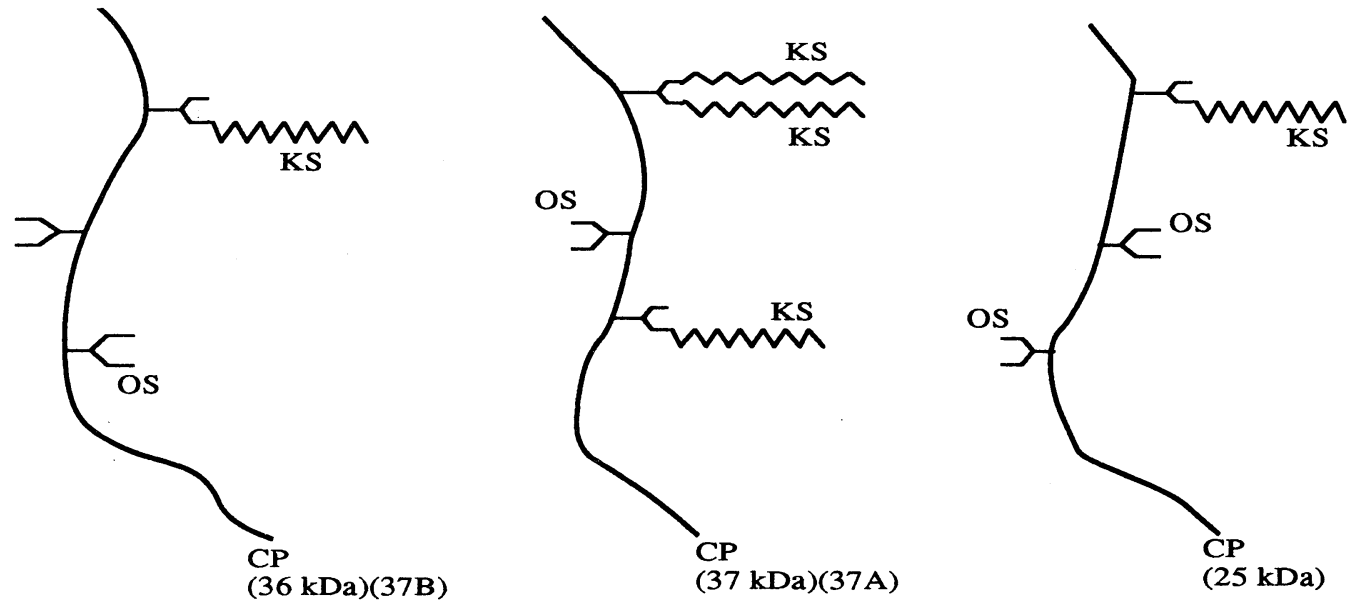

Fig. 1. Models for three isoforms of KSPGs. CP: core protein; KS: keratan sulfate; OS: oligosaccharide

This stimulating work opens new avenues to answer questions like; if transparency of the cornea is related to KSPG are all forms required? If not, do these three forms have additional physiological functions? The regulation of metabolism of these forms are likely to be different. Do these molecules express themselves differentially during the process of development?

\section{Reported by Shridhar P. Damle}

Eye Research Institute

Boston, Massachusetts, USA.
かれたと思われる。角膜の透明化にKSPGが関与しているとし たら、この全ての異型が要るだろうか？もし要らないなら、こ れらの3本の異型は別の生理的な機能を持っているのだろうか? これらの代謝の制御はそれぞれ異なっているだろうか? 発生過 程の時に、これらの分子は差次的に発現されてくるのだろう か。

\section{三菱化成生命科学研究所 · 複合糖質研究室 \\ 山形達也 訳}

